\title{
Role of photosynthesis and stomatal conductance on the long-term rising of intrinsic water use efficiency in dominant trees in three old- growth forests in Bosnia-Herzegovina and Montenegro
}

\author{
Chiara Palandrani ${ }^{(1-2)}$, \\ Renzo Motta ${ }^{(3)}$, \\ Paolo Cherubini ${ }^{(4-5)}$, \\ Milic Čurović( ${ }^{(6)}$, \\ Vojislav Dukić (7), \\ Giustino Tonon ${ }^{(8)}$, \\ Christian Ceccon ${ }^{(8)}$, \\ Alessandro Peressotti (2), \\ Giorgio Alberti ${ }^{(2-9)}$
}

\begin{abstract}
$\square$ (1) Department of Life Sciences, University of Trieste, v. Weiss 2, 1-34128 Trieste (Italy); (2) Department of Agricultural, Food, Environmental and Animal Sciences, University of Udine, v.le delle Scienze 206, I-33100 Udine (Italy); (3) Department of Agriculture, Forestry and Food Sciences, University of Turin, l.go Paolo Braccini 2, I-10095 Grugliasco, TO (Italy); (4) WSL Swiss Federal Research Institute, $\mathrm{CH}-8903$ Birmensdorf, (Switzerland); (5) Faculty of Forestry, University of British Columbia, Vancouver BC (Canada); (6) University of Montenegro, Biotechnical Faculty, Mihaila Lalica 1, Podgorica (Montenegro); (7) Faculty of Forestry, University of Banja Luka, Bulevar vojvode Stepe Stepanovica 75 a, 78000 Banja Luka (Bosnia and Herzegovina); (8) Faculty of Science and Technology, Libera Università di Bolzano, I-39100 Bolzano (Italy); (9) CNRIBIMET, v. Caproni 8, I-50145 Firenze (Italy)
\end{abstract}

@ Chiara Palandrani (claire.13@hotmail.it)

Received: Mar 27, 2020 - Accepted: Nov 30, 2020

Citation: Palandrani C, Motta R, Cherubini P, Čurović M, Dukić V, Tonon G, Ceccon C, Peressotti A, Alberti G (2021). Role of photosynthesis and stomatal conductance on the long-term rising of intrinsic water use efficiency in dominant trees in three oldgrowth forests in Bosnia-Herzegovina and Montenegro. iForest 14: 53-60. - doi: 10.3832/ifor3414-013 [online 2021-01-28]

Communicated by: Rossella Guerrieri

Old-growth forests have an important role in maintaining animal and plant diversity, are important carbon $(C)$ reservoirs and are privileged sites to study long-term plant physiological responses, long-term forest dynamics and climate change impact on forest ecosystems. Several studies have highlighted how old-living trees undergo age-related declines with hydraulic limitations and reduction in photosynthesis, though some recent works have suggested that such a decline is not always observed. Our study aims at understanding the role of atmospheric $\mathrm{CO}_{2}$ increase on tree $\mathrm{C}$ uptake and stomatal conductance $\left(g_{s}\right)$ in old-living trees by analysing the long-term patterns of tree growth and intrinsic water use efficiency (iWUE) in three old-growth forests in the Balkans (Bosnia-Herzegovina and Montenegro), using dendrochronology and isotopic analysis. We hypothesised a long-term increase in iWUE in the studied old-growth forests, mostly related to enhanced photosynthesis rather than reduced stomatal conductance. Tree cores were sampled from dominant silver fir (Abies alba Mill.) trees in each forest. Tree-ring widths were measured and basal area increments (BAI) were assessed for each sampled tree and, from the six longest chronologies, five decades were chosen for cellulose extraction, its isotopic analysis $\left(\delta^{13} \mathrm{C}, \delta^{18} \mathrm{O}\right)$, iWUE and leaf water ${ }^{18} \mathrm{O}$ evaporative enrichment above the source water $\left(\Delta^{18} \mathrm{O}_{\mathrm{L}}\right)$ determination. We observed a continuous and significant increase in iWUE from 1800 to 2010 in the sampled dominant trees at all the three old-growth forests. Our BAl data and our estimates of $\Delta^{18} \mathrm{O}_{\mathrm{L}}$ across the study period support the idea that enhanced photosynthesis rather than reduced stomatal conductance is the major driver of the measured iWUE increase. Thus, our results support some recent findings challenging the hypothesis that iWUE in forests is primarily the result of a $\mathrm{CO}_{2}$-induced reduction in stomatal conductance as well as the so called hydraulic limitation hypothesis.

Keywords: Old-growth Forests, Intrinsic Water-Use Efficiency (iWUE), Basal Area Increment, Stable $\mathrm{C}$ Isotopes, Atmospheric $\mathrm{CO}_{2}$ Increase

\section{Introduction}

Human activities have caused approximately $1.0^{\circ} \mathrm{C}$ of global warming in 2020 above values recorded in pre-industrial times, with important changes in the intensity and the frequency of some climate and weather extremes (IPCC 2018). Warming caused by anthropogenic greenhouse gases emissions (GHGs) will persist for centuries to millennia (Matthews \& Caldeira 2008, Solomon et al. 2009) and will continue to cause further long-term changes either in the climate system or in the biosphere. In particular, atmospheric $\mathrm{CO}_{2}$ concentration has been constantly rising in the last centuries because of human activities, reaching in the 2000 s the highest levels over the last 160,000 years (IPCC 2014). In forest ecosystems, climate change is altering productivity, species distribution, tree physiology and pest disease severity and frequency, with widespread tree mortality phenomena (Allen et al. 2010, Anderegg et al. 2012, Lindner et al. 2014, Seidl et al. 2014, 2018). However, increase in $\mathrm{CO}_{2}$ atmos- pheric concentration can stimulate tree growth, can modify plant physiology and finally affect forest dynamics (Magnani et al. 2007, Ciais et al. 2008, Lewis et al. 2009, Pretzsch et al. 2014). Indeed, elevated $\mathrm{CO}_{2}$ concentrations can stimulate tree growth due to enhanced photosynthesis (Ainsworth \& Long 2005). Moreover, higher atmospheric $\mathrm{CO}_{2}$ levels $\left(\mathrm{C}_{\mathrm{a}}\right)$ usually lead to stomata closure, thus decreasing transpiration rates and increasing assimilation rates (Serna 2014, Xu et al. 2016). This leads to an improvement of water use efficiency (WUE) defined as the ratio between photosynthesis (A) and transpiration. Multiplying WUE by vapour pressure deficit (VPD) yields to the intrinsic water use efficiency (iWUE $=\mathrm{A} / \mathrm{g}_{s}$, where $\mathrm{g}_{s}$ is the stomatal conductance), which is not sensitive to increased transpiration driven by abiotic changes (Ehleringer et al. 1993, Saurer et al. 2004). Higher iWUE values, coupled with faster tree growth measured by treering width and converted into basal area increment (BAI), have been previously re- 
ported for several forests and linked to the increase in atmospheric $\mathrm{CO}_{2}$ (Feng 1999, Liu et al. 2007, Saurer et al. 2014). However this relationship has been not always confirmed (Marshall \& Monserud 1996, Waterhouse et al. 2004, Van Der Sleen et al. 2015) as an increase in iWUE alone may not directly translate into higher BAl as other factors (e.g., high temperature, recurrent drought, nutrient limitation) may negatively influence tree growth (Tognetti et al. 2014). More recently, Guerrieri et al. (2019) reported an increase in iWUE in the last thirty years in 8 North America mature temperate forests and linked it to an overall increase in photosynthesis rather than to a reduction in stomatal conductance at most sites.

Tree rings offer insight into lifetime growth patterns, allowing climate impacts on trees to be evaluated (Fritts 1976). On the other hand, stable carbon (C) isotopes represent a useful tool to better understand changes in tree growth and productivity related to climate conditions through time. The variability of the $C$ isotopic signature $\left(\delta^{13} \mathrm{C}\right)$ in wood gives information about the plant's sensitivity to different climatic and environmental conditions (McCarroll \& Loader 2006). C isotope discrimination $\left(\Delta^{13} C\right)$ can be related to $\mathrm{CO}_{2}$ flux through stomata and to changes in $\mathrm{C}_{\mathrm{a}}$ to intercellular $\mathrm{CO}_{2}$ concentration $\left(\mathrm{C}_{\mathrm{i}}\right)$ gradient and, by consequence, to iWUE (Francey \& Farquhar 1982, Farquhar et al. 1989). However, the extent to which rising $C_{a}$ has affected long-term iWUE, and whether climate could explain deviations from expected $C_{a^{-}}$ induced growth enhancement, is still poorly understood (Tognetti et al. 2014). On the other hand, environmental variation of $\delta^{18} \mathrm{O}$ in tree rings reflects the wide range of variation in meteoric water, soil water and transpiration (Gessler et al. 2014). Barbour \& Farquhar (2000) found a strong relationship between leaf water evaporative enrichment $\left(\Delta^{18} \mathrm{O}_{\mathrm{L}}\right)$ and $\mathrm{g}_{\mathrm{s}}$. Moreover, the same authors proposed an equation describing the relationship between $\Delta^{18} \mathrm{O}_{\mathrm{L}}$ and
${ }^{18} \mathrm{O}$ enrichment of cellulose $\left(\Delta^{18} \mathrm{O}_{c}\right)$, taking into account the exchange of carbonyl oxygen with unenriched xylem water. Based on these findings, the derived $\Delta^{18} \mathrm{O}_{\mathrm{L}}$ was used to constrain the contribution of stomatal conductance in driving observed changes in iWUE (Guerrieri et al. 2019).

Old-growth stands have developed for a long period of time without relevant human impact and/or stand replacing or major natural disturbances, and have three main structural characteristics: old and large trees, abundant coarse woody debris in different decay stages and a multilayered vertical structure (Spies 2004). Oldgrowth forests have an important role in maintaining animal and plant diversity, are important $C$ reservoirs and are privileged sites to study long-term plant physiological responses, long-term forest dynamics and climate change impact on forest ecosystems (Motta et al. 2011). Old-growth forests have been often considered to be insignificant as carbon sinks because of an equilibrium between assimilation and respiration (Odum 1969). This hypothesis is based on studies showing a decline in net primary productivity at stand level with stand age (Yoder et al. 1994, Gower et al. 1996, Ryan et al. 1997) and in photosynthesis at tree level (Hubbard et al. 1999) and the general idea that ecosystem respiration increases with stand age (Odum 1969). Some recent works have suggested that such a decline is not always observed at stand level (Luyssaert et al. 2008, Yu et al. 2008) and that old-growth forests are still accumulating $C$, as stand structure rather than age determines the overall forest capacity to absorb $C$ from the atmosphere (Zhou et al. 2006, Luyssaert et al. 2008, Phillips et al. 2008). However, as far as single trees are concerned, it has been proved that taller trees differ physiologically from shorter, younger trees (Ryan et al. 2006): several studies have highlighted how oldliving trees undergo age-related declines with hydraulic limitations (i.e., reduction in stomatal conductance and in leaf-specific

Tab. 1 - Mean stand characteristics at each experimental site $(L O M=$ Lom; PER = Perucica; $\mathrm{BIO}=$ Biogradska Gora). Mean \pm standard error $(n=30)$.

\begin{tabular}{|c|c|c|c|c|}
\hline \multirow{2}{*}{\multicolumn{2}{|c|}{ Variable }} & \multicolumn{3}{|c|}{ Site } \\
\hline & & LOM & PER & BIO \\
\hline \multicolumn{2}{|c|}{ Stand Density $\left(\mathrm{n} \mathrm{ha}^{-1}\right)$} & $489.0 \pm 19^{\mathrm{a}}$ & $432.0 \pm 21^{\mathrm{ab}}$ & $412.0 \pm 22^{b}$ \\
\hline \multicolumn{2}{|c|}{ Mean Diameter $(\mathrm{cm})$} & $35.4 \pm 0.8^{\mathrm{a}}$ & $41.7 \pm 1.6^{b}$ & $43.2 \pm 1.8^{\mathrm{b}}$ \\
\hline \multicolumn{2}{|c|}{ Total Basal Area $\left(\mathrm{m}^{2} \mathrm{ha}^{-1}\right)$} & $47.1 \pm 1.8^{\mathrm{a}}$ & $59.1 \pm 4.5^{b}$ & $60.1 \pm 4.4^{\mathrm{b}}$ \\
\hline \multirow{3}{*}{$\begin{array}{l}\text { Total Species } \\
\text { Density }\left(\mathrm{n} \mathrm{ha}^{-1}\right)\end{array}$} & Fir & $122.0 \pm 9.0^{\mathrm{a}}$ & $90.0 \pm 13^{a}$ & $92.0 \pm 11^{\mathrm{a}}$ \\
\hline & Beech & $296.0 \pm 13^{a}$ & $337.0 \pm 20^{\mathrm{a}}$ & $298.0 \pm 21^{\mathrm{a}}$ \\
\hline & Spruce & $69.0 \pm 9.0^{\mathrm{a}}$ & $6.0 \pm 2.0^{b}$ & $10.0 \pm 3.0^{b}$ \\
\hline \multirow{3}{*}{$\begin{array}{l}\text { Species Basal } \\
\text { Area }\left(\mathrm{m}^{2} \mathrm{ha}^{-1}\right)\end{array}$} & Fir & $22.2 \pm 1.6^{\mathrm{a}}$ & $39.5 \pm 4.7^{\mathrm{b}}$ & $34.1 \pm 4.7^{\mathrm{ab}}$ \\
\hline & Beech & $14.3 \pm 0.7^{\mathrm{a}}$ & $17.0 \pm 1.5^{\mathrm{a}}$ & $18.7 \pm 2.1^{\mathrm{a}}$ \\
\hline & Spruce & $10.4 \pm 1.5^{\mathrm{a}}$ & $2.6 \pm 1.2^{b}$ & $5.6 \pm 2.0^{b}$ \\
\hline \multicolumn{2}{|c|}{ Number of Sampled Trees (Fir) } & 28 & 43 & 7 \\
\hline
\end{tabular}

hydraulic conductance) and reduction in photosynthesis (Yoder et al. 1994, Ryan \& Yoder 1997, Ryan et al. 2006). In this context, we focused our attention on old-living silver fir (Abies alba Mill.) trees in three mixed old-growth forests in the Balkans with the aim to better understand the relationship between growth dynamics, atmospheric $\mathrm{CO}_{2}$ concentration increase and climate conditions through time. By measuring cellulose $\delta^{13} \mathrm{C}$ in tree-rings, the present study hypothesised an increase in the iWUE of old-living silver trees during the last two centuries. Moreover, using cellulose $\delta^{18} \mathrm{O}$ data and $\mathrm{BAl}$ we tested the hypothesis that the increase in iWUE was mostly related to enhanced photosynthesis rather than reduced stomatal conductance.

\section{Materials and methods}

\section{Study area}

Three study sites were selected in three different old-growth forests, along a 100 $\mathrm{km}$ transect from North-west to Southeast, in the Balkans, in South-eastern Europe (Fig. S1 in Supplementary mayterial). All of the three sites are in the montane belt and are mixed with silver fir (Abies alba Mill.), Norway spruce (Picea abies Karst), and European beech (Fagus sylvatica L.).

The first site (LOM) is located in the Lom forest reserve $\left(44^{\circ} 27^{\prime} \mathrm{N}, 16^{\circ} 28^{\prime} \mathrm{E}\right.$; 1250 $1500 \mathrm{~m}$ a.s.l.) in the Dinaric Alps in Bosnia and Herzegovina. Climate is continental with maritime airstream influences. Mean annual precipitation is about $1600 \mathrm{~mm}$ and mean annual temperature is $7.6^{\circ} \mathrm{C}$ (Bottero et al. 2011).

The second site (PER) is located in the Perućica forest reserve $\left(43^{\circ} 19^{\prime} \mathrm{N}, 18^{\circ} 40^{\prime} \mathrm{E}\right.$; 600-2800 $\mathrm{m}$ a.s.l.), inside the Sutjeska National Park in the southern Dinaric Mountains, Bosnia and Herzegovina. Climate is a mix of Mediterranean and continental, with mean annual precipitation of 1400 $\mathrm{mm}$ and mean annual temperature of 11.3 ${ }^{\circ} \mathrm{C}$ (Nagel \& Svoboda 2008).

The third site (BIO) is located in the $\mathrm{Na}$ tional Park of Biogradska Gora $\left(42^{\circ} 53^{\prime} \mathrm{N}\right.$, $19^{\circ} 36^{\prime} \mathrm{E} ; 830-2100 \mathrm{~m}$ a.s.l.) in the northeastern part of Bjelasica mountain range, Montenegro (Motta et al. 2015). The mean annual precipitation at Biogradsko lake (1093 m a.s.l.) is $1962 \mathrm{~mm}$, with a mean annual temperature of $5{ }^{\circ} \mathrm{C}$.

\section{Tree sampling and dendrochronological} analysis

To characterize the forest's structure, a regular 120-m grid was superimposed to the 1:10.000 raster map of each forest and 30 to 40 sampling points were randomly selected at each site (in 2014, 2016 and 2017 in PER, LOM and BIO sites, respectively). At each point, a $615.5 \mathrm{~m}^{2}$ circular plot was set up for the measurements of the living trees $(\mathrm{dbh} \geq 7.5 \mathrm{~cm})$, tree species were assessed and tree mean diameter at $1.30 \mathrm{~m}$ (dbh) 
was measured (Motta et al. 2015). Moreover, one permanent plot ( 1 ha) was set up for long-term monitoring purposes at each forest.

For the purposes of this study, we decided to consider only silver fir as it was the dominant species in term of basal area at all sites (Tab. 1), because of its longevity and because it mostly occupied the upper canopy layer (PER is reported in Fig. S2 as example). Thus, one tree core was taken at the bottom of the stem from 7-43 individuals of silver fir within the top canopy layer (i.e., the tallest trees in the stand) depending on the site (Tab. 1, Fig. S2 in Supplementary material), using an increment borer. Cores were stored in cardboard and, once in laboratory, samples were glued on woody supports and sanded with paper with 60, 120, 240, 320 and 600 grit to better highlight tree rings.

Tree-ring widths were measured for each core using a LINTABTM (Frank Rinn, Heidelberg, Germany) and then were visually cross-dated using TSAPWin ${ }^{\oplus}$ software ver. 4.81 (Rinntech-Metriwerk CmbH \& Co. KG, Heidelberg, Germany). COFECHA software (Grissino-Mayer 2001, Holmes 1983) was used for the statistical cross-date and to check chronologies quality (Castagneri et al. 2014).

\section{Isotopes analysis}

From all the samples at each site, the six longest chronologies were selected. Then, tree rings for each core were grouped using 10-year intervals, cut and separately milled using an ultra-centrifugal mill with a sieve of $0.5 \mathrm{~mm}\left(\mathrm{ZM} 100^{\oplus}\right.$, Retsch Tecnology, Haan, Germany). In order to have enough replications at each plot, we considered only five consecutive time-intervals along each time-series for the further analysis (1800-1810; 1850-1860; 1900-1910; 19501960; 2000-2010). Wood powder was treated with a two-step digestion to extract cellulose according to Green (1963). Briefly, samples were sealed in Teflon bags and at first treated two times with $\mathrm{NaOH}$ $5 \%$ solution for 2 hours at $60^{\circ} \mathrm{C}$. Then, samples were treated with $\mathrm{NaClO}_{2} 7 \%$ solution, adjusting the $\mathrm{pH}$ to $4-5$ with acetic acid, for 10 hours at $60{ }^{\circ} \mathrm{C}$. Depending on sample weight and its cellulose content, this phase was repeated for three or four times until samples totally bleached, thus indicating that all fibres but cellulose were completely digested. Dried sub-samples were finally weighted in tin capsules for $\delta^{13} \mathrm{C}$ for analysis using a CHNS elemental analyser (Vario Microcube ${ }^{\oplus}$, Elementar, Langenselbold, Germany) coupled with a stable isotope ratio mass spectrometer (IRMS Isoprime $^{\circledast} 100$, Elementar). We also determined $\delta^{18} \mathrm{O}$ of a sub-sample of cellulose weighted in silver capsules for each considered time period using a TC/EA elemental analyser (Flash $2000^{\oplus}$, ThermoScientific, Waltham, MA, USA) connected to an isotope ratio mass spectrometer (Delta $V$ Advantage $^{\circledast}$, Thermo Scientific) via a continu- ous flow interface (ConFlo IV ${ }^{\circledR}$, Thermo Scientific). Carbon and oxygen isotope ratios were expressed in per mil (\%) relative to the Vienna Pee Dee Belemnite (VPDB) and Vienna Standard Mean Ocean Water (VSMOW) international standards, respectively.

\section{Data analysis}

The $C$ isotopic discrimination $\left(\Delta^{13} C\right)$ for each selected period and tree was calculated according to Farquhar et al. (1982 eqn. 1)

$$
\Delta^{13} C=\frac{\delta^{13} C_{a}-\delta^{13} C_{c}}{1+\frac{\delta^{13} C_{c}}{1000}}
$$

where $\delta^{13} C_{a}$ is the isotopic signature of atmosphere and $\delta^{13} C_{c}$ is the isotopic signature of the cellulose. As our $\delta^{13} C_{c}$ values represent an average value for 10-year intervals, $\delta^{13} C_{a}$ were calculated as the mean value for the same temporal interval of the relative $\delta^{13} C_{c}$ measurements using values published in McCarroll \& Loader (2006) and those from Mauna Loa Observatory since 2003 (https://www.esrl.noaa.gov/gm d/).

We used the carbon isotope discrimination model for $\mathrm{C} 3$ plants (eqn. 2) proposed by Farquhar et al. (1982) and Francey \& Farquhar (1982) to compute intercellular $\mathrm{CO}_{2}$ concentration $\left(\mathrm{C}_{\mathrm{i}}, \mathrm{ppm}\right)$ based on $\triangle^{13} \mathrm{C}$ and atmospheric $\mathrm{CO}_{2}$ concentration $\left(C_{a}, p p m\right.$; data from Mauna Loa Observatory - http:// www.esrl.noaa.gov/gmd/):

$$
\begin{aligned}
\Delta^{13} C & =a+\frac{(b-a) \cdot C_{i}}{C_{a}} \cdot C_{i} \\
& =C_{a} \cdot \frac{\left(\delta^{13} C_{a}-\delta^{13} C_{c}-a\right)}{(b-a)}
\end{aligned}
$$

where $a$ is isotope fractionation during $\mathrm{CO}_{2}$ diffusion through stomata $(a=4.4 \%), b$ is isotope fractionation during carboxylation processes $(b=27 \%)$. According to the Fick's law, net photosynthesis (A) can be calculated as follows (eqn. 3):

$$
A=g_{\mathrm{CO}_{2}} \cdot\left(C_{a}-C_{i}\right)
$$

where $\mathrm{g}_{\mathrm{CO} 2}$ is the leaf conductance to $\mathrm{CO}_{2}$. Knowing that leaf conductance to water vapour $\left(\mathrm{g}_{\mathrm{H} 2 \mathrm{O}}\right)$ is equal to $1.6 \cdot \mathrm{g}_{\mathrm{CO}_{2}}$, we calculated $\mathrm{iWUE}\left(\mu \mathrm{molCO}_{2} \mathrm{molH}_{2} \mathrm{O}^{-1}\right)$, expressed as the ratio between photosynthesis and stomatal conductance to $\mathrm{H}_{2} \mathrm{O}\left(\mathrm{A} / \mathrm{g}_{\mathrm{H} 2 \mathrm{O}}\right) \mathrm{com}$ bining all the previous equations (eqn. 4):

$$
\text { iWUE }=\frac{A}{g_{\mathrm{H}_{2} \mathrm{O}}}=\frac{\frac{C_{a}}{1.6} \cdot b-\Delta^{13} C}{b-a}
$$

We also calculated the ${ }^{18} \mathrm{O}$ enrichment of cellulose $\left(\Delta^{18} \mathrm{O}_{c}\right)$ according to eqn. 5 :

$$
\Delta^{18} O_{C}=\frac{\delta^{18} O_{C}-\delta^{18} O_{P}}{1+\frac{\delta^{18} O_{P}}{1000}}
$$

where $\delta^{18} \mathrm{O}_{\mathrm{p}}$ is the annual $\delta^{18} \mathrm{O}$ of the pre- cipitation estimated following Barbour et al. (2001 - eqn. 6):

$$
\begin{aligned}
\delta^{18} O_{P} & =0.52 \cdot T_{a}-0.006 \cdot T_{a}^{2} \\
& +2.42 \cdot P_{a}-1.43 \cdot P_{a}^{2} \\
& -0.046 \cdot \sqrt{E}-13.0
\end{aligned}
$$

where $T_{a}, P_{a}$ and $E$ are the mean annual temperature $\left({ }^{\circ} \mathrm{C}\right)$, the annual precipitation ( $m$ ) and the elevation of the weather station $(\mathrm{m})$, respectively. We assumed that there were no differences among trees in the depth water was taken up and, thus, that the soil water $\delta^{18} \mathrm{O}$ reflected precipitation $\delta^{18} \mathrm{O} . \delta^{18} \mathrm{O}_{\mathrm{p}}$ was computed as the average between the values of the weather station located in Sarajevo $\left(43.8678^{\circ} \mathrm{N}\right.$, $18.4228^{\circ} \mathrm{E}-630 \mathrm{~m}$ a.s.l.; data availability: 1901-2019) and the one located Zagreb $\left(45.8167^{\circ} \mathrm{N}, 15.9781^{\circ} \mathrm{E}-157 \mathrm{~m}\right.$. a.s.l.; data availability: 1881-2019) as these two stations showed similar rain and temperature averages across all the data period. Climate data were downloaded from Global Historical Climatology Network website (GHCND). Long term $\delta^{18} \mathrm{O}_{\mathrm{P}}$ trends at the two stations are reported in Fig. S3 (Supplementary material).

We finally estimated the leaf water ${ }^{18} \mathrm{O}$ evaporative enrichment above the source water $\left(\triangle^{18} \mathrm{O}_{\mathrm{L}}\right)$ according to Barbour \& Farquhar (2000) and Gessler et al. (2014):

$$
\Delta^{18} O_{L}=\frac{\Delta^{18} O_{C}-\varepsilon_{W C}}{1-p_{x} p_{e x}}
$$

where $p_{e x}$ is the proportion of exchangeable oxygen in cellulose formed from sucrose, $p_{x}$ is the proportion of unenriched (source) water in the developing cambium cell and $\varepsilon_{w c}$ is the isotope fractionation occurring during cellulose synthesis in the stem (27\%). Generally, a fixed value of 0.40 is considered for $p_{x} p_{e x}$.

Yearly basal area increment $\left(\mathrm{BAl}_{\mathrm{i}}, \mathrm{cm}^{2} \mathrm{yr}^{-1}\right)$ was calculated using tree-ring width as follows (eqn. 8):

$$
\begin{aligned}
\text { BAI }_{i} & =\pi \cdot\left(R_{i+1}^{2}-R_{i}^{2}\right) \\
& =\pi \cdot\left[\left(R_{i}+\Delta r_{i}\right)^{2}-R_{i}^{2}\right] \\
& =\pi \cdot\left(\Delta r_{i}^{2}+2 \cdot \Delta r_{i} \cdot \sum_{i=1}^{n-1} \Delta r_{i}\right)
\end{aligned}
$$

where $R_{i+1}$ is the radius at the end of the year $i$ and $R_{i}$ is the radius at the beginning of the year $i, \Delta r_{i}$ is the tree-ring width at year $i$.

\section{Statistical analysis}

All statistical analyses were performed using R software ver. 3.6.0 (R Foundation for Statistical Computing 2019 - https://www.rproj.org). We compared iWUE, $\mathrm{C}_{\mathrm{i}}, \Delta^{18} \mathrm{O}_{\mathrm{L}}$ and $\mathrm{BAI}$ in the selected decades at each site by using one-way ANOVA and Tukey's posthoc test when significant $(p<0.05)$ differences were detected. All data were eventually log-transformed before analysis to meet the requirements for parametric statistical tests using "powerTransform" and "bcPower" functions of the "car" package (Fox \& Weisberg 2019). Linear regressions were used to explain changes in iWUE with 


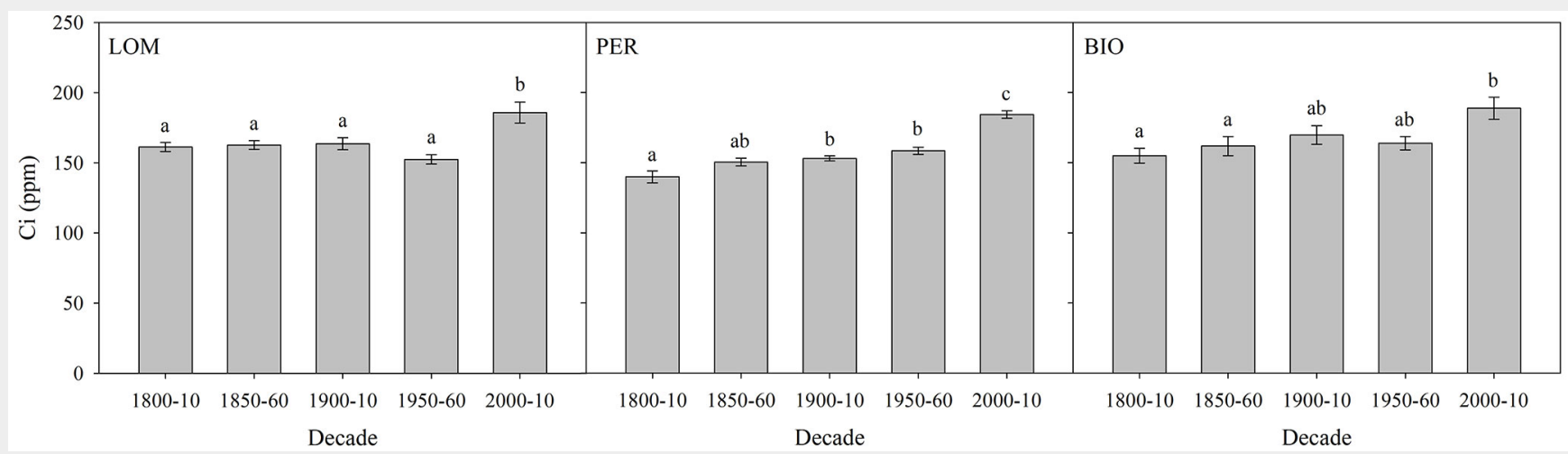

Fig. 1 - Intercellular $\mathrm{CO}_{2}$ concentration $\left(\mathrm{C}_{\mathrm{i}}, \mathrm{ppm}\right)$ by selected decades at the three old-growth forests (PER: Perucica; LOM: Lom; BIO: Biogradska Gora). Means \pm standard error are displayed. Different letters indicate significant $(\mathrm{p}<0.05)$ differences among periods after post-hoc Tukey's test.

BAl; before regression, data normality was checked using the Shapiro-Wilk test. All data throughout the text and in tables and figures are reported as mean \pm standard error.

\section{Results}

The mean stand characteristics at each experimental site are reported in Tab. 1. Total stem density ranged from $412 \pm 22$ to $489 \pm 19$ trees ha-1 at BIO and LOM, respectively, but total basal area followed an opposite trend, being the highest at LOM and the lowest at BIO $(60.1 \pm 4.4$ and $47.1 \pm 1.8$ $\mathrm{m}^{2}$ ha $^{-1}$, respectively). European beech was the dominant species in terms of stem density $\left(n \mathrm{ha}^{-1}\right)$ at all the three sites, but silver fir was always dominant in terms of basal area $\left(\mathrm{m}^{2} \mathrm{ha}^{-1}\right)$. The oldest measured tree ring series were 306, 267 and 273-year-old in LOM, PER and BIO, respectively, though it was not always possible to reach the centre of the stem.

$C_{i}$ significantly increased through time at all sites (LOM: $p<0.001$; PER: $p<0.001$; BIO: $\mathrm{p}=0.01$ - Fig. 1; Tab. S1 in Supplementary material) and was significantly related to $C_{a}$ (LOM: $\mathrm{R}^{2}=0.57, \quad \mathrm{p}<0.001 ;$ PER: $\mathrm{R}^{2}=0.93$, $\left.\mathrm{p}<0.001 ; \mathrm{BIO}: \mathrm{R}^{2}=0.64, \mathrm{p}<0.001\right)$. We did not find any significant difference in the ratio $\mathrm{C}_{\mathrm{i}} / \mathrm{C}_{\mathrm{a}}$ at $\mathrm{BIO}(\mathrm{p}=0.06)$, but a significant decrease in $C_{i} / C_{a}$ was measured for the periods 1950-1960 and 2000-2010 at LOM $(p<0.001)$ and for the period $2000-2010$ at PER ( $p=0.04$ - Fig. S4, Tab. S5 in Supplementary material). Trees also showed a significant increase in their iWUE, as well as in their BAl, at all sites (Fig. 2; Tab. S2, Tab.
S3), reaching significant higher values especially at the end of the last century.

As far as $\delta^{18} \mathrm{O}_{c}$ is concerned, we did not detect any significant difference among the selected periods at all the three sites (data not shown; $p>0.05$ ). Moreover, we observed no changes in $\Delta^{18} \mathrm{O}_{L}$ at all the three sites for the periods when $\delta^{18} \mathrm{O}_{P}$ was available (1900-1910; 1950-1960; 2000-2010; p>0.05 - Fig. 2, Tab. S4 in Supplementary material).

Fir trees showed a significant increase in BAI with time (Fig. 2, Fig. 3; Tab. S2 in Supplementary material) at all the three experimental sites, especially after the beginning of the $19^{\text {th }}$ century. BIO had generally the highest growth rate, though it showed a slight decline in the last two decades, while fir at PER had generally the lowest growth,
Fig. 2 - Intrinsic water-use efficiency (iWUE, $\mu \mathrm{molCO}$ $\mathrm{molH}_{2} \mathrm{O}^{-1}$ ), basal area increment (BAI, $\mathrm{cm}^{2} \mathrm{yr}^{-1}$ ) and leaf water evaporative enrichment $\left(\Delta^{18} \mathrm{O}_{\mathrm{L}}\right)$ by selected decades at the three old-growth forests (PER: Perucica; LOM: Lom; BIO_Biogradska Gora). Means \pm standard error are displayed. Different letters indicate significant $(p<0.05)$ differences among periods after posthoc Tukey's test.
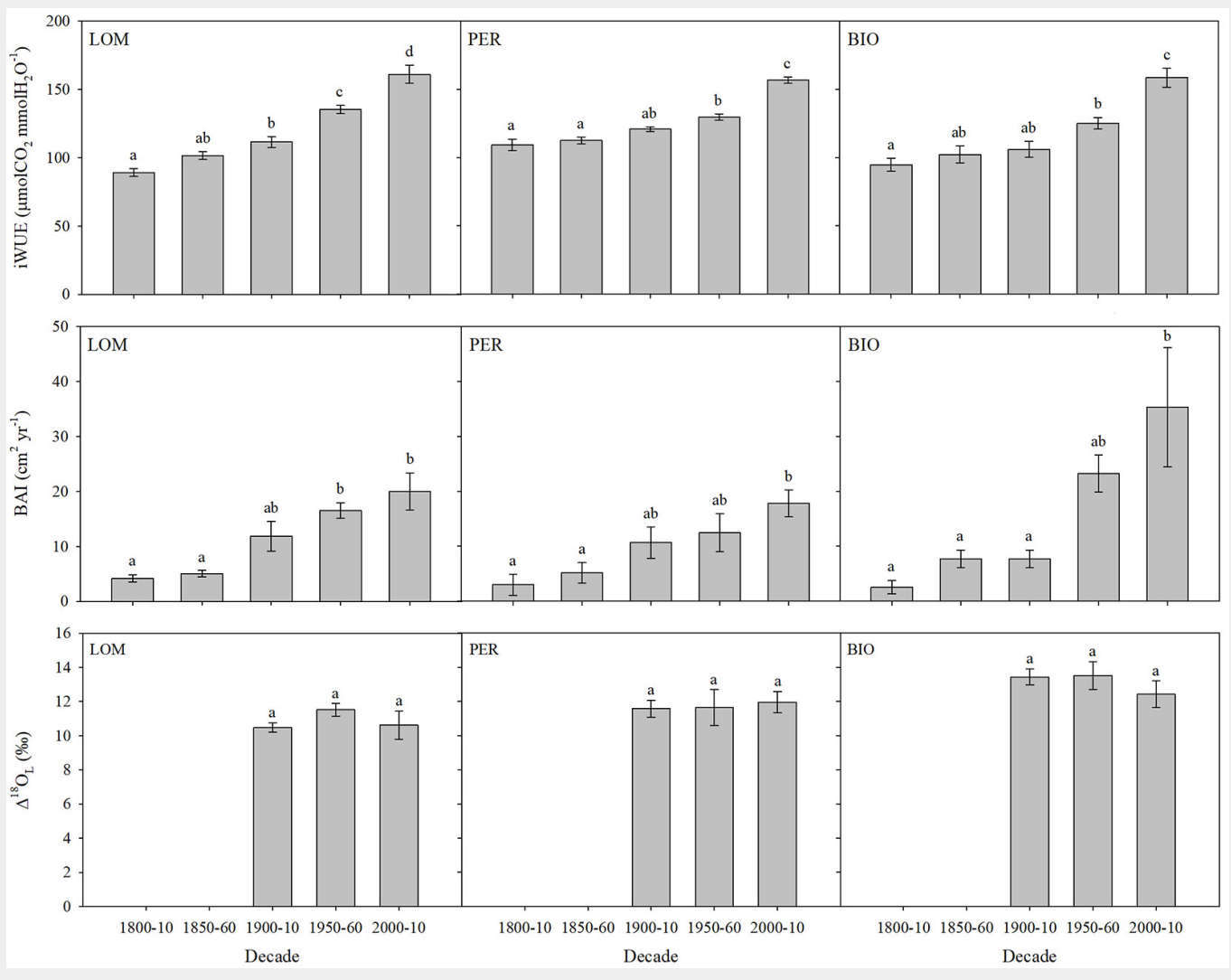
but did not show any decrease in growth with time.

Using simple linear regressions, we found that iWUE significantly increase with BAI at all sites (LOM: $\mathrm{R}^{2}=0.68, \mathrm{p}<0.0001$; PER: $\mathrm{R}^{2}=0.42, \mathrm{p}=0.0003 ; \mathrm{BIO}: \mathrm{R}^{2}=0.45, \mathrm{p}=0.0002$ - Fig. 4; Tab. S6 in Supplementary material).

\section{Discussion}

In our study, iWUE showed a significant increase in the last two centuries at LOM, PER and BIO, (Fig. 2, Tab. S3). These trends are similar to those measured in a wide range of ecosystems (Peñuelas et al. 2011, Silva \& Anand 2013, Frank et al. 2015) either in temperate (Waterhouse et al. 2004, Saurer \& Siegwolf 2007, Guerrieri et al. 2019) or tropical/sub-tropical forests (Wu et al. 2015, Wils et al. 2016), as well as at single experimental sites (Battipaglia et al. 2013) or across the whole Europe (Saurer et al. 2014), but none of these studies considered old-growth forests.

Variations in both $\mathrm{A}$ and $\mathrm{g}_{\mathrm{s}}$ influence the overall change in iWUE (Ehleringer et al. 1993, Saurer et al. 2004). The increase in atmospheric $\mathrm{CO}_{2}$ concentration positively affects $A$ by increasing the carboxylation rate of Rubisco (Drake et al. 1997, Ainsworth \& Long 2005, Huang et al. 2007) and positively influences tree growth rate (Linares et al. 2009, Streit et al. 2013). In our case, $C_{i}$ increased proportionally to $C_{a}, C_{i} / C_{a}$ stayed constant over the last two hundred years (BIO) or slightly decreased at the end of last century (PER, BIO). The measured increase in $C_{i}$ is consistent with what reported by Frank et al. (2015) for Europe and by Guerrieri et al. (2019) for North America and might indicate that the increase in $\mathrm{CO}_{2}$ concentration is sustaining photosynthesis and the growth of the sampled dominant trees (Fig. 3) - the so called " $\mathrm{CO}_{2}$ fertilization effect on A" (McCarroll \& Loader 2004, Guerrieri et al. 2019). We were not able to quantify the absolute increase in BAl for the whole stand $\left(\mathrm{m}^{2}\right.$ ha-1 $\left.\mathrm{yr}^{-1}\right)$ and to disentangle the role of climate change from small scale stand disturbance dynamics (i.e., release from suppression),

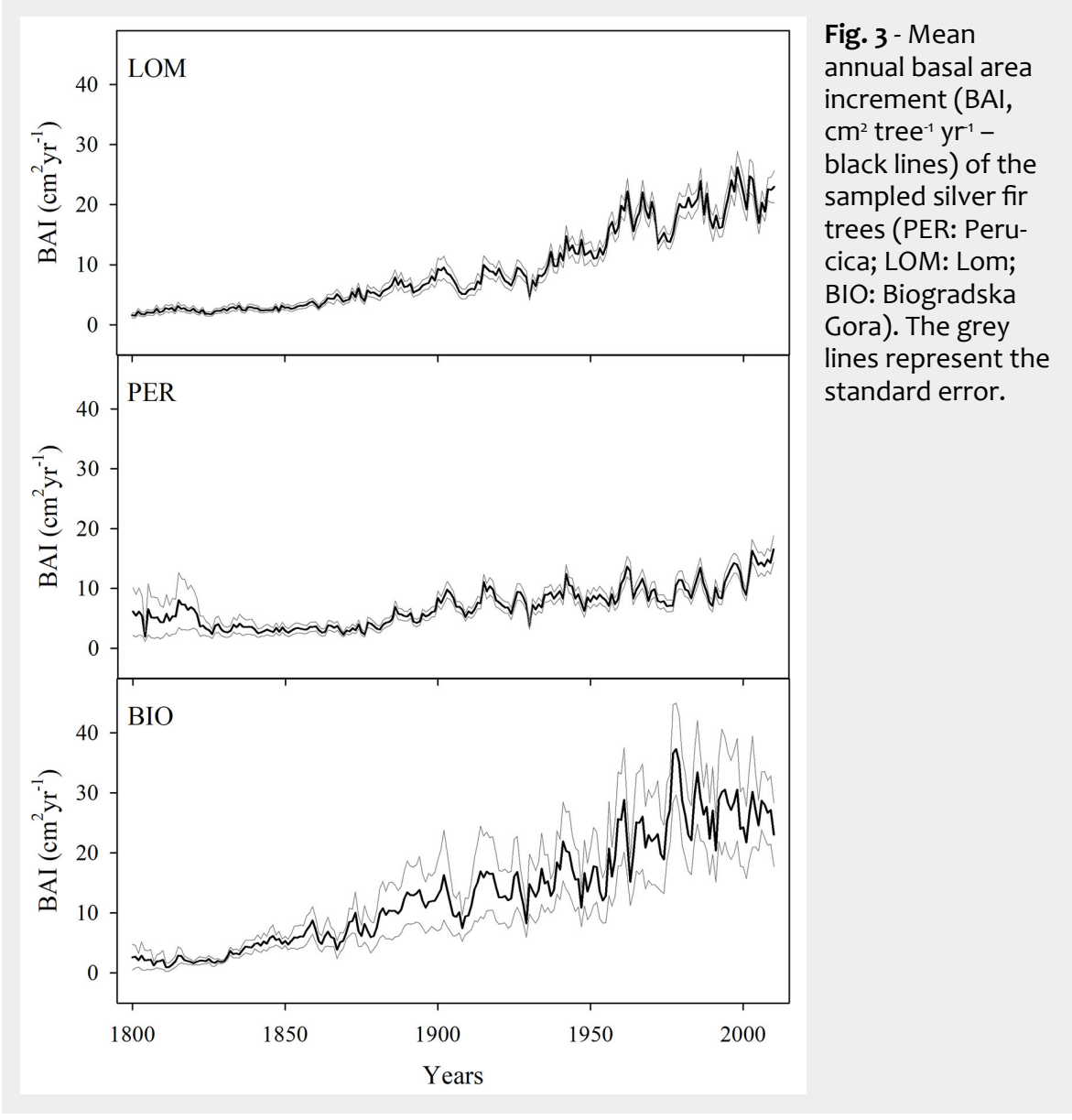

because of our sampling strategy. In fact, time. But, the trend in BAl reported in Fig. taller trees may differ physiologically from 3 can be considered a proxy of an overall shorter, younger trees (Ryan et al. 2006) increase at stand level in the last decades. and the selection of only dominant trees Looking at Fig. 3, the sampled dominant within the stands might over-estimate ab- trees did not show any significant decrease solute growth rates ("slow-grower sur- in tree growth after well-known heatvivorship bias" and "big tree selection waves, such as that in 2003: these results bias" - Cherubini et al. 1998, Brienen et al. seem to further confirm the high resistance 2012, Nehrbass-Ahles et al. 2014, Duchesne of fir to drought extremes observed in et al. 2019). On the other, silver fir has the other regions (Zang et al. 2014, Vitali et al. capacity for vigorous growth response af- 2017) and the possibility of the species to ter releases related to natural disturbances cope with the climate change (Vitasse et al. of the top-canopy layer or to management 2019). The measured increase in BAl and (Ferlin 2002) and this makes it difficult to the resistance to drought could be particudisentangle the $\mathrm{CO}_{2}$ fertilization effect over larly important for the Dinaric Region,

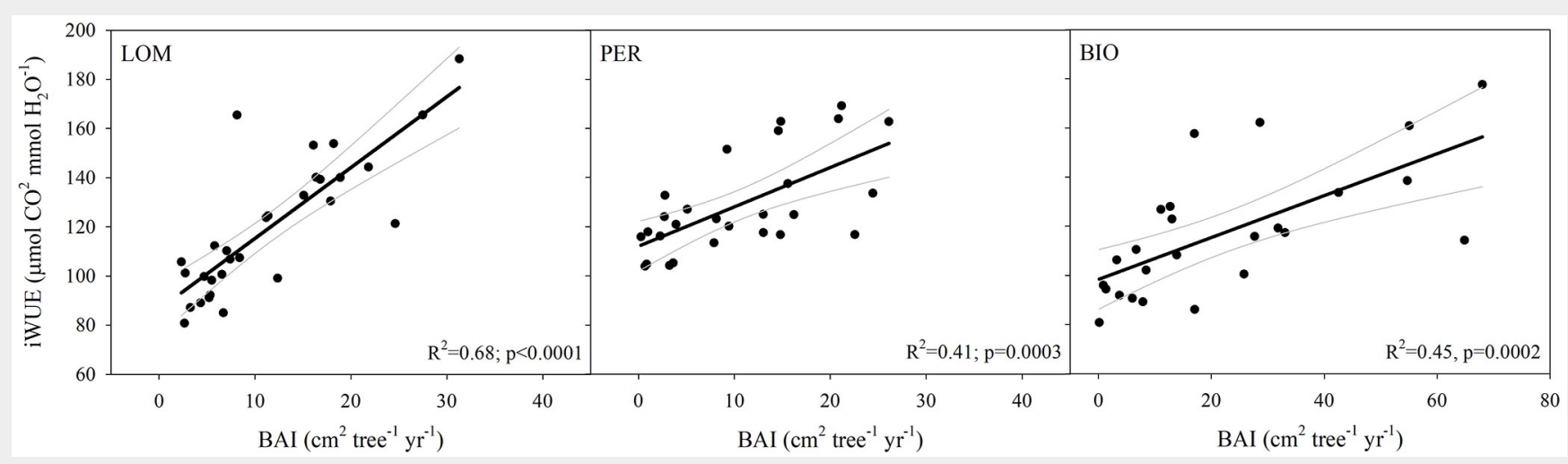

Fig. 4 - Basal area increment (BAl, $\mathrm{cm}^{2}$ tree-1 $\mathrm{yr}^{-1}$ ) with increasing intrinsic water-use efficiency (iWUE, $\mathrm{mmolCO}_{2} \mathrm{molH}_{2} \mathrm{O}^{-1}$ ). Each point represents a selected decade for each sampled tree. Black line represents the regression line and grey lines represent $95^{\text {th }}$ confidence intervals. 
where silver fir has been one of the most ecologically and economically important tree species, mainly managed using the selection system (Boncina 2011).

On the other hand, increasing $C_{a}$ may induce stomata closure and, thus, plants may improve their iWUE by reducing water loss by transpiration (Farquhar et al. 1989, McCarroll \& Loader 2004). Fir, in particular, has been reported to be able to efficiently control its transpiration (Nourtier et al. 2014). In our case, as we did not observe any change in $\Delta^{18} \mathrm{O}_{L}$, we can hypothesize a constant $g_{s}$ over the last two centuries similarly to what has been reported by Guerrieri et al. (2019) for mesic sites in North America in the last thirty years. This and the positive correlation between iWUE and $\mathrm{BAl}$ at all our three old-growth forest sites (Fig. 4, Tab. S6 in Supplementary material) further support the hypothesis that the measured increase in iWUE over time is more related to a stimulation of $A$ rather than a reduction in $\mathrm{g}_{\mathrm{s}}$. A widely held assumption is that, after an initial period of increasing growth, the mass growth rate of individual trees declines with increasing tree size (Weiner \& Thomas 2001). On the contrary, Stephenson et al. (2014) have shown that mass growth rate increases continuously with tree size in hundreds of tree species. Our BAI data suggest that large, old trees do not act simply as senescent carbon reservoirs, but actively fix large amounts of $\mathrm{C}$ and have been growing even faster in the last decades. These data are in agreement with the substantial increase in silver fir growth rate measured across several European regions probably promoted by warmer climate as well as by the increase in nitrogen depositions and atmospheric $\mathrm{CO}_{2}$ concentrations (Bosela et al. 2014, 2018, Cavlović et al. 2015, Gazol et al. 2015). Thus, the overall $C$ sink potential of old-growth forests might be higher than previously thought as old-living dominant trees are not undergoing any age-related growth decline. The lower juvenile tree growth is also supporting the hypothesis that such a $C$ sink capacity will be maintained for a longer period of time as trees will show a slower ontogeny (Büntgen et al. 2019).

\section{Conclusions}

In the last two centuries, we observed a continuous increase in iWUE in silver fir at all the three old-growth forest sites in the Balkans. By estimating leaf water $\delta^{18} \mathrm{O}$ from cellulose isotopic analysis in tree rings and using BAl measurements, we were able to separate the relative contribution of assimilation rates $(A)$ and stomatal conductance $\left(g_{s}\right)$. In particular, we observed an increase in iWUE, BAI, but not in $\delta^{18} \mathrm{O}_{\mathrm{L}}$. Thus, our data support some recent findings challenging the hypothesis that iWUE in forests is primarily the result of a $\mathrm{CO}_{2}$-induced reduction in stomatal conductance. Moreover, our data support the idea that silver fir might cope with the climate change.

\section{Aknowledgements}

We would like to thank: the team of University of Turin (Department of Agriculture, Forestry and Food Sciences), Italy for helping during sampling in Bosnia-Herzegovina and in Montenegro; the team of WSL (Swiss Federal Institute for Forest, Snow and Landscape Research) in Birmensdorf, Switzerland for helping during cellulose extraction procedures in the lab; Gaia Zanin for sample processing and data analysis of the tree cores taken in Perucica forest in 2014.

\section{References}

Ainsworth EA, Long SP (2005). What have we learned from 15 years of free-air $\mathrm{CO}_{2}$ enrichment (FACE)? A meta-analysis review of the responses of photosynthesis, canopy properties and plant production to rising $\mathrm{CO}_{2}$. New Phytologist 165 (2): 351-372. - doi: 10.1111/j.1469-8137.20 04.01224.x

Allen CD, Macalady AK, Chenchouni H, Bachelet $D$, McDowell D, Vennetier M, Kitzberger T, Rigling $A$, Bershears DD, Hogg $E H$, Gonzalez $P$, Fensham R, Zhang Z, Castro J, Demidova N, Lim JH, Allard G, Running SW, Semerci A, Cobb N (2010). A global overview of drought and heatinduced tree mortality reveals emerging climate change risks for forests. Forest Ecology and Management 259 (4): 660-684. - doi: 10.101 6/j.foreco.2009.09.001

Anderegg WRL, Kane JM, Anderegg LDL (2012). Consequences of widespread tree mortality triggered by drought and temperature stress. Nature Climate Change 3: 30-36. - doi: 10.1038/n climate1635

Barbour MM, Andrews TJ, Farquhar GD (2001). Correlations between oxygen isotope ratios of wood constituents of Quercus and Pinus samples from around the world. Australian Journal of Plant Physiology 28: 335-348. [online] URL: http://www.publish.csiro.au/FP/PP00083

Barbour MM, Farquhar GD (2000). Relative humidity- and ABA-induced variation in carbon and oxygen isotope ratios of cotton leaves. Plant, Cell and Environment 23: 473-485. - doi: 10.1046/j.1365-3040.2000.00575.x

Battipaglia G, Saurer M, Cherubini P, Calfapietra C, McCarthy HR, Norby RJ, Cotrufo MF (2013). Elevated $\mathrm{CO}_{2}$ increases tree-level intrinsic water-use efficiency: insights from carbon and oxygen isotope analyses in tree rings across three forest FACE sites. New Phytologist 197 (2): 544-554. - doi: 10.1111/nph.12044

Boncina A (2011). History, current status and future prospects of uneven-aged forest management in the Dinaric region: an overview. Forestry 84: 467-478. - doi: 10.1093/forestry/cpro23 Bosela M, Petrás R, Sitková Z, Priwitzer T, Pajtík J, Hlavatá H, Sedmák R, Tobine B (2014). Possible causes of the recent rapid increase in the radial increment of silver fir in the Western Carpathians. Environmental Pollution 184: 211221. - doi: 10.1016/j.envpol.2013.08.036

Bosela M, Lukac M, Castagneri D, Sedmák R, Biber P, Carrer M, Konôpka B, Nola P, Nagel TA, Popa I, Roibu CC, Svoboda M, Trotsiuk V, Büntgen $U$ (2018). Contrasting effects of environmental change on the radial growth of co-occurring beech and fir trees across Europe. Sci- ence of The Total Environment 615: 1460-1469. doi: 10.1016/j.scitotenv.2017.09.092

Bottero A, Garbarino M, Dukic V, Govedar Z, Lingua E, Nagel TA, Motta R (2011). Gap-phase dynamics in the old-growth forest of Lom, Bosnia and Herzegovina. Silva Fennica 45 (5): 875-887. - doi: 10.14214/sf.76

Brienen RJW, Gloor E, Zuidema PA (2012). Detecting evidence for $\mathrm{CO}_{2}$ fertilization from tree ring studies: the potential role of sampling biases. Global Biogeochemical Cycles 26 (1): GB1025. - doi: 10.1029/2011GB004143

Büntgen U, Krusic PJ, Piermattei A, Coomes DA, Esper J, Myglan VS, Kirdyanov AV, Camarero JJ, Crivellaro A, Körner C (2019). Limited capacity of tree growth to mitigate the global greenhouse effect under predicted warming. Nature Communications 10: 2171. - doi: 10.1038/s41467019-10174-4

Castagneri D, Nola P, Motta R, Carrer M (2014). Summer climate variability over the last 250 years differently affected tree species radial growth in a mesic Fagus-Abies-Picea old-growth forest. Forest Ecology and Management 320: 21-29. - doi: 10.1016/j.foreco.2014.02.023

Cavlović J, Bončina A, Boić $M$, Goršić $E$, Simončič T, Teslak K (2015). Depression and growth recovery of silver fir in uneven-aged Dinaric forests in Croatia from 1901 to 2001. Forestry 88: 856-598. [online] URL: http://academic.oup.co $\mathrm{m} /$ forestry/article/88/5/586/523578

Cherubini P, Dobbertin M, Innes JL (1998). Potential sampling bias in long-term forest growth trends reconstructed from tree rings: a case study from the Italian Alps. Forest Ecology and Management 109: 103-118. - doi: 10.1016/SO3 78-1127(98)00242-4

Ciais P, Schelhaas MJ, Zaehle S, Piao SL, Cescatti A, Liski J, Luyssaert S, Le-Maire G, Schulze ED, Bouriaud O, Freibauer A, Valentini R, Nabuurs GJ (2008). Carbon accumulation in European forests. Nature Geoscience 1: 425-429. - doi: 10.1038/ngeo233

Drake GB, Gonzàlez-Meler MA, Long SP (1997). More efficient plants: a consequence of rising atmospheric $\mathrm{CO}_{2}$ ? Annual Review of Plant Physiology and Plant Molecular Biology 48: 609-639. - doi: 10.1146/annurev.arplant.48.1.609

Duchesne L, Houle D, Ouimet R, Caldwell L, Gloor M, Brienen R (2019). Large apparent growth increases in boreal forests inferred from tree-rings are an artefact of sampling biases. Scientific Reports 9 (1): 1431. - doi: 10.1038/ s41598-019-43243-1

Ehleringer JR, Hall AE, Farquhar GD (1993). Introduction: water use in relation to productivity. In: "Stable Isotopes and Plant Carbon-Water Relations" (Ehleringer JR, Hall AE, Farquhar GD eds). Academic Press, New York, USA, pp. 3-8. Farquhar GD, Leary MH, Berry JA (1982). On the relationship between carbon isotope discrimination and the intercellular carbon dioxide concentration in leaves. Australian Journal of Plant Physiology 9 (2): 121-137. [online] URL: http:// www.publish.csiro.au/FP/PP9820121

Farquhar GD, Ehleringer JR, Hubick KT (1989). Carbon isotope discrimination and photosynthesis. Annual Review of Plant Physiology and Plant Molecular Biology 40: 503-537. - doi: 10.1146/annurev.pp.40.060189.002443

Feng $X$ (1999). Trends in intrinsic water-use effi- 
ciency of natural trees for the past 100-200 years: a response to atmospheric concentration. Geochimica et Cosmochimica Acta 63 (13 14): 1891-1903. - doi: 10.1016/So016-7037(99)0o0 88-5

Ferlin (2002). The growth potential of understorey silver fir and Norway spruce for unevenaged forest management in Slovenia. Forestry 75: 375-383. - doi: 10.1093/forestry/75.4.375

Fox J, Weisberg S (2019). An R companion to applied regression ( $3^{\text {rd }}$ edn). Sage, Thousand Oaks, CA, USA, pp. 576. [online] URL: http://us. sagepub.com/en-us/nam/an-r-companion-to-ap plied-regression/book246125

Francey RJ, Farquhar GD (1982). An explanation for the ${ }^{12} \mathrm{C} /{ }^{13} \mathrm{C}$ variations in tree rings. Nature 297: 28-31. - doi: 10.1038/297028ao

Frank DC, Poulter B, Saurer M, Esper J, Huntingford C, Helle G, Treydte K, Zimmermann NE, Schleser $\mathrm{GH}$, Ahlström A, Ciais P, Friedlingstein $P$, Levis S, Lomas A, Sitch S, Viovy N, AndreuHayles L, Bednarz Z, Berninger F, Boettger $T$, DAlessandro CM, Daux V, Filot $M$, Grabner $M$, Gutierrez E, Haupt $M$, Hilasvuori E, Jungner $H$, Kalela-Brundin M, Krapiec M, Leuenberger $M$, Loader NJ, Marah H, Masson-Delmotte V, Paz dur A, Pawelczyk S, Pierre M, Planells O, Pukiene R, Reynolds-Henne CE, Rinne KT, Saracino A, Sonninen E, Stievenard M, Switsur VR, Szczepanek M, Szychowska-Krapiec E, Todaro L, Waterhouse JS, Weigl M (2015). Water-use efficiency and transpiration across European forests during the Anthropocene. Nature Climate Change 5 (6): 579-583. - doi: $10.1038 /$ nclim ate 2614

Fritts HC (1976). Tree rings and climate. Academic Press, London, UK, pp. 567.

Gazol A, Camarero JJ, Gutiérrez E, Popa I, Andreu-Hayles L, Motta R, Nola P, Ribas M, Sangüesa-Barreda G, Urbinati C (2015). Distinct effects of climate warming on populations of silver fir (Abies alba) across Europe. Journal of Biogeography 42 (6): 1150-1162. - doi: 10.1111/jbi.1 2512

Gessler A, Ferrio JP, Hommel R, Treydte K, Wernerm RA, Monson RK (2014). Stable isotopes in tree rings: towards a mechanistic understanding of isotope fractionation and mixing processes from the leaves to the wood. Tree Physiology 34: 796-818. - doi: 10.1093/treephys/tpuo 40

Green JW (1963). Wood cellulose. Methods in Carbohydrate Chemistry 3: 9-21.

Gower ST, McMurtrie RE, Murty D (1996). Aboveground net primary production decline with stand age: potential causes. Trends in Ecology and Evolution 11 (9): 378-382. - doi: 10.1016/0169-5347(96)10042-2

Grissino-Mayer HD (2001). Evaluating crossdating accuracy: a manual and tutorial for the computer program COFECHA. Tree-Ring Research 57 (2): 205-221. [online] URL: http://repository. arizona.edu/handle/10150/251654

Guerrieri R, Belmecheri S, Ollinger SV, Asbjornsen $H$, Jennings $K$, Xiao J, Stocker BD, Martin $M$, Hollinger DY, Bracho-Garrillo R, Clark F, Dore S, Kolb T, Munger JW, Novick K, Richardson AD (2019). Disentangling the role of photosynthesis and stomatal conductance on rising forest water-use efficiency. Proceedings of the $\mathrm{Na}$ tional Academy of Sciences USA 116: 16909-
16914. - doi: 10.1073/pnas.1905912116

Holmes RL (1983). Computer-assisted quality control in tree-ring dating and measurements. Tree Ring Bulletin 43: 69-78. [online] URL: http://repository.arizona.edu/handle/10150/2612 23

Huang JG, Bergeron Y, Denneler B, Berninger F, Tardif J (2007). Response to forest trees to increased atmospheric $\mathrm{CO}_{2}$. Critical Reviews in Plant Sciences 26 (5-6): 265-283. - doi: 10.1080/ 07352680701626978

Hubbard RM, Bond BJ, Ryan MG (1999). Evidence that hydraulic conductance limits photosynthesis in old Pinus ponderosa trees. Tree Physiology 19 (3): 165-172. - doi: 10.1093/treeph ys/19.3.165

IPCC (2014). Climate change 2014: synthesis report. Contribution of Working Groups I, II and III to the Fifth Assessment Report of the Intergovernmental Panel on Climate Change (Core Writing Team, Pachauri RK, Meyer LA eds). IPCC, Geneva, Switzerland, pp. 151.

IPCC (2018). Summary for policymakers. In: "Global warming of $1.5{ }^{\circ} \mathrm{C}$ " (Masson-Delmotte V, Zhai P, Pörtner HO, Roberts D, Skea J, Shukla PR, Pirani A, Moufouma-Okia W, Péan C, Pidcock R, Connors S, Matthews JBR, Chen J, Zhou $X$, Gomis MI, Lonnoy $\mathrm{E}$, Maycock T, Tignor $M$, Waterfield T eds). World Meteorological Organization, Geneva, Switzerland, pp. 32.

Lewis SL, Lopez-Gonzalez G, Sonké B, AffumBaffoe K, Barker TR, Ojo L, Phillips O, Reitsman J, White L, Comiskey J, Djuikouo MN, Ewango C, Feldpausch T, Hamilton A, Gloor M, Hart T, Hladik A, Lloyd J, Lovett J, Makana JR, Malhi Y, Mbago F, Ndangalasi J, Peacock J, Peh K, Sheil D, Sunderland T, Swaine M, Taplin J, Tayor D, Thomas S, Votere R, Wöll H (2009). Increasing carbon storage in intact African tropical forests. Nature 457: 1003-1006. - doi: 10.1038/natu reo7771

Linares JC, Camarero JJ, Carreira JA (2009). Interacting effects of changes in climate and forest cover on mortality and growth of the southernmost European fir forests. Global Ecology and Biogeography 18 (4): 485-497. - doi: 10.1111/ j.1466-8238.2009.00465.x

Lindner M, Fitzgerald J, Zimmermann N, Reyer C, Delzon S, Van Der Maaten E, Schelhaas MJ, Lasch P, Eggers J, Van Der Maaten-Theunissen M, Suckow F, Psomas A, Poulter B, Hanekinkel $M$ (2014). Climate change and European forests: what do we now, what are the uncertainties, and what are the implications for forest management? Journal of Environmental Management 146: 69-83. - doi: 10.1016/j.jenvman.20 14.07.030

Liu X, Shao X, Liang E, Zhao L, Chen T, Qin D, Ren $J$ (2007). Species dependent responses of juniper and spruce to increasing $\mathrm{CO}_{2}$ concentration and to climate in semi-arid and arid areas of northwestern China. Plant Ecology 193: 195209. - doi: 10.1007/s11258-006-9258-5

Luyssaert S, Schhulze ED, Börner A, Knohl A, Hessenmöller D, Law BE, Ciais P, Borner JC (2008). Old-growth forest as global carbon sinks. Nature 455: 213-215. - doi: 10.1038/nature 07276

Magnani F, Mencuccini $M$, Borghetti $M$, Berbigier $\mathrm{P}$, Berninger $\mathrm{F}$, Delzon $\mathrm{S}$, Grelle A, Hari $\mathrm{P}$, Jarvis PG, Kolari P, Kowalski AS, Lankreijer H,
Law BE, Lindroth A, Loustau D, Manca G, Moncrieff $G B$, Rayment $M$, Tedeschi $V$, Valentini R, Grace J (2007). The human footprint in the carbon cycle of temperate and boreal forests. Nature 447: 849-851. - doi: 10.1038/nature05847 Marshall JD, Monserud RA (1996). Homeostatic gas-exchange parameters inferred from ${ }^{13} \mathrm{C} /{ }^{12} \mathrm{C}$ in tree rings of conifers. Oecologia 105 (1): 13-21. - doi: $10.1007 / B F 00328786$

Matthews HD, Caldeira K (2008). Stabilizing climate requires near-zero emissions. Geophysical Research Letters 35 (4): CogSo5. - doi: 10.1029/ 2007GL032388

McCarroll D, Loader NJ (2004). Stable isotopes in tree rings. Quaternary Science Reviews 23: 78.), 771-801. - doi: 10.1016/j.quascirev.2003.06.0 17

McCarroll D, Loader NJ (2006). Isotopes in tree rings. In: "Developments in Paleoenvironmental Research", vol. 10 (Leng MJ ed). Kluwer Academic Publishers, Dordrecht, Netherlands, pp. 67-116. - doi: 10.1007/1-4020-2504-1_02

Motta R, Berretti R, Castagneri D, Dukić V, Garbarino M, Govedar Z, Lingua E, Maunaga Z, Meloni $F$ (2011). Toward a definition of the range of variability of central European mixed Fagus-Abies-Picea forests: the nearly steadystate forest of Lom (Bosnia and Herzegovina). Canadian Journal of Forest Research 41 (9): 1871-1884. - doi: 10.1139/x11-098

Motta R, Garbarino M, Berretti R, Bjelanovic I, Borgogno-Mondino E, Curović M, Keren S, Meloni F, Nosenzo A (2015). Structure, spatio-temporal dynamics and disturbance regime of the mixed beech-silver fir-Norway spruce oldgrowth forest of Biogradska Gora (Montenegro). Plant Biosystems 149 (6): 966-975. - doi: 10.1080/11263504.2014.945978

Nagel TA, Svoboda M (2008). Gap disturbance regime in an old-growth Fagus-Abies forest in the Dinaric Mountains, Bosnia-Herzegovina. Canadian Journal of Forest Research 38 (11): 2728 2737. - doi: 10.1139/Xo8-110

Nehrbass-Ahles C, Babst F, Klesse S, Nötzli M, Bouriaud O, Neukom R, Dobbertin M, Frank D (2014). The influence of sampling design on tree-ring-based quantification of forest growth. Global Change Biology 20: 2867-2885. - doi: 10.1111/gcb.12599

Nourtier M, Chanzy A, Cailleret M, Yingge X, Huc R, Davi H (2014). Transpiration of silver fir (Abies alba Mill.) during and after drought in relation to soil properties in a Mediterranean mountain area. Annals of Forest Science 71 (6): 683-695. - doi: 10.1007/s13595-012-0229-9

Odum EP (1969). Strategy of ecosystem development. Science 164: 262-270. - doi: $10.1126 / \mathrm{sci}$ ence. 164.3877 .262

Peñuelas J, Canadell JG, Ogaya R (2011). Increased water-use efficiency during the $20^{\text {th }}$ century did not translate into enhanced tree growth. Global Ecology and Biogeography 20 (4): 597-608. - doi: 10.1111/j.1466-8238.2010.006 08.x

Phillips NG, Buckley TN, Tissue DT (2008). Capacity of old trees to response to environmental change. Journal of Integrative Plant Biology 50 (11): 1355-1364. - doi: 10.1111/j.1744-7909.2008. 00746.x

Pretzsch H, Biber P, Schütze G, Uhl E, Rötzer T (2014). Forest stand growth dynamics in Cen- 
tral Europe have accelerated since 1870 . Nature Communications 5 (1): 1065. - doi: 10.1038/ncom ms5967

Ryan MG, Phillips N, Bond NJ (2006). The hydraulic limitation hypothesis revisited. Plant, Cell and Environment 29 (3): 367-381. - doi: 10.1111/j.1365-3040.2005.01478.x

Ryan M, Binkley D, Fownes J (1997). Age-related decline in forest productivity: pattern and process. In: “Advances in Ecological Research”, vol. 27, Elsevier, Netherlands, pp. 213-262. - doi: 10.1016/So065-2504(08)60009-4

Ryan MG, Yoder BJ (1997). Hydraulic limits to tree height and tree growth. Bioscience 47 (4): 235-242. - doi: 10.2307/1313077

Saurer M, Siegwolf RTW, Schweingruber FH (2004). Carbon isotope discrimination indicates improving water-use efficiency of trees in northern Eurasia over the last 100 years. Global Change Biology 10 (12): 2109-2120. - doi: 10.1111/ j.1365-2486.2004.00869.x

Saurer M, Siegwolf RTW (2007). Human impacts on tree-ring growth reconstructed from stable isotopes. In: "Stable Isotopes as Indicators of Ecological Change" (Dawson TE, Siegwolf RTW eds). Academic Press, London, UK, pp. 49-62. doi: 10.1016/S1936-7961(07)01004-4

Saurer M, Spahni R, Frank DC, Joos F, Leuenberger M, Loader NJ, McCarroll D, Gagen M, Poulter B, Siegwolf RTW, Andreau-Hayles L, Boettger T, Liñan ID, Fairchild IJ, Friedrich $M$, Gutierrez E, Haupt M, Hilasvuori E, Heinrich I, Helle G, Grudd H, Jalkanen R, Levanič T, Linderholm HW, Robertson I, Sonninen E, Treydte K, Waterhouse JS, Woodley EJ, Wynn PM, Young GHF (2014). Spatial variability and temporal trends in water-use efficiency of European forests. Global Change Biology 20 (12): 37003712. - doi: 10.1111/gcb.12717

Seidl R, Klonner G, Rammer W, Essl F, Moreno A, Neumann M, Dullinger S (2018). Invasive alien pests threaten the carbon stored in Europe's forests. Nature Communications 9: 1626. - doi: 10.1038/s41467-018-04096-w

Seidl R, Schelhaas MJ, Rammer W, Verkerk PJ (2014). Increasing forest disturbances in Europe and their impact on carbon storage. Nature Climate Change 4: 806-810. - doi: 10.1038/n climate 2318

Serna L (2014). Drawing the future. Plant Signaling and Behavior 3 (4): 214-217. - doi: 10.4161/ps b.3.4.5280

Silva LCR, Anand M (2013). Probing for the influence of atmospheric $\mathrm{CO}_{2}$ and climate change on forest ecosystem across biomes. Global Ecology and Biogeography 22 (1): 83-92. - doi: 10.1111/j.1466-8238.2012.00783.x

Solomon S, Plattner GK, Knutti R, Friedlingstein $P$ (2009). Irreversible climate change due to carbon dioxide emissions. Proceedings of the National Academy of Sciences USA 106: 17041709. - doi: 10.1073/pnas.0812721106

Spies TA (2004). Ecological concepts and diversity of old-growth forests. Journal of Forestry 102 (3): 14-20. [online] URL: http://academic. oup.com/jof/article/102/3/14/4613151
Stephenson NL, Das AJ, Condit R, Russo SE, Baker PJ, Beckman NG, Coomes DA, Lines ER, Morris WK, Rüger N, Álvarez E, Blundo C, Bunyavejchewin S, Chuyong G, Davies SJ, Duque Á, Ewango CN, Flores O, Franklin JF, Grau HR, Hao Z, Harmon ME, Hubbell SP, Kenfack D, Lin Y, Makana J-R, Malizia A, Malizia LR, Pabst RJ, Pongpattananurak N, Su S-H, Sun I-F, Tan F, Thomas D, van Mantgem PJ, Wang X, Wiser SK, Zavala MA (2014). Rate of tree carbon accumulation increases continuously with tree size. Nature 507: 90-93. - doi: 10.1038/nature12914

Streit K, Siegwolf RTW, Hagedorn F, Schaub M, Buchman N (2013). Lack of photosynthetic or stomatal regulation after 9 years of elevated $\mathrm{CO}_{2}$ and 4 years of soil warming in two conifers species in the alpine treeline. Plant, Cell and Environment 37 (2): 315-326. - doi: 10.1111/pce.12197 Tognetti R, Lombardi F, Lasserre B, Cherubini P, Marchetti M (2014). Tree-ring stable isotopes reveal twentieth-century increases in water-use efficiency of Fagus sylvatica and Nothofagus spp. in Italian and Chilean mountains. PLoS One 9 (11): e113136. - doi: 10.1371/journal.pone.01131 36

Van Der Sleen P, Groenendijk P, Vlam M, Anter NPR, Boom A, Bongers F, Pons TL, Terburg G, Zuidema PA (2015). No growth stimulation of tropical trees by 150 years of $\mathrm{CO}_{2}$ fertilization but water-use efficiency increased. Nature Geoscience 8: 24-28. - doi: 10.1038/ngeo2313

Vitali V, Buntgen U, Bauhus J (2017). Silver fir and Douglas fir are more tolerant to extreme droughts than Norway spruce in south-western Germany. Global Change Biology 23 (12): 51085119. - doi: 10.1111/gcb.13774

Vitasse $\mathrm{Y}$, Bottero A, Rebetez $\mathrm{M}$, Conedera $\mathrm{M}$, Augustin S, Brang P, Tinner W (2019). European Journal of Forest Research 138 (4): 547-560. doi: 10.1007/s10342-019-01192-4

Waterhouse JS, Switsur VR, Barker AC, Carter AHC, Hemming DL, Loader NJ, Robertson I (2004). Northern European trees show a progressively diminishing response to increasing atmospheric carbon dioxide concentrations. Quaternary Science Reviews 23 (7-8): 803-810. doi: 10.1016/j.quascirev.2003.06.011

Weiner J, Thomas SC (2001). The nature of tree growth and the "age-related decline in forest productivity”. Oikos 94 (2): 374-376. [online] URL: https://www.jstor.org/stable/3547583 Wils THG, Robertson I, Woodborne S, Hall G, Koprowski M, Eshetu Z (2016). Anthropogenic forcing increases the water-use efficiency of African trees. Journal of Quaternary Science 31 (4): 386-390. - doi: 10.1002/jqs.2865

Wu G, Liu X, Chen T, Xu G, Wang W, Zeng X, Wang B, Zhang $X$ (2015). Long-term variation of tree growth and intrinsic water-use efficiency in Schrenk spruce with increasing $\mathrm{CO}_{2}$ concentration and climate warming in the western Tianshan Mountains, China. Acta Physiologiae Plantarum 37 (8): 660. - doi: 10.1007/s11738-015-190 3-y

Xu Z, Jiang $\mathrm{Y}$, Jia B, Zhou G (2016). Elevated- $\mathrm{CO}_{2}$ response of stomata and its dependence on en- vironmental factors. Frontiers in Plant Science 7 (19120): 258. - doi: 10.3389/fpls.2016.00657 Yoder BJ, Ryan MG, Waring RH, Schoettle AW, Kaufmann MR (1994). Evidence of reduced photosynthetic rates in old trees. Forest Science 40 (3): 513-527. [online] URL: http://acad emic.oup.com/forestscience/article-abstract/40 /3/513/4627183

Yu G, Liu Y, Wang X, Ma K (2008). Age-dependent tree-ring growth responses to climate in Qilian juniper (Sabina przewalskii Kom.). Trees 22 (2): 197-204. - doi: 10.1007/s00468-007-0170-y Zang C, Hartl-Meier C, Dittmar C, Rothe A, Menzel A (2014). Patterns of drought tolerance in major European temperate forest trees: climatic drivers and levels of variability. Global Change Biology 20 (12): 3767-3779. - doi: 10.1111/ gcb.12637

Zhou G, Liu SG, Li Z, Zhang D, Tang X, Zhou C, Yan J, Mo J (2006). Old-growth forests can accumulate carbon in soils. Science 314 (5804): 1417-1417. - doi: 10.1126/science.1130168

\section{Supplementary Material}

Fig. S1 - Location of the three experimental sites.

Fig. S2 - Distribution of the standing trees by diameter and height class within the 1ha permanent plot in Perucica and relative distribution of the sampled fir trees by diameter and height class in the same plot.

Fig. $\mathbf{S 3}-\delta^{18} \mathrm{O}$ of the precipitation estimated following Barbour et al. (2001 - eqn. 8) at the weather station in Sarajevo and in Zagreb.

Fig. S4 - Ratio between intercellular $\mathrm{CO}_{2}$ concentration $\left(\mathrm{C}_{\mathrm{i}}\right)$ and atmospheric $\mathrm{CO}_{2}$ concentration $\left(C_{a}\right)$ by selected decades at the three old-growth forests.

Tab. S1 - ANOVA results for intercellular $\mathrm{CO}_{2}$ concentration $C_{i}$ by selected decades.

Tab. S2 - ANOVA results for basal area increment (BAI) by selected decades.

Tab. S3 - ANOVA results for intrinsic water use efficiency (iWUE) by selected decades.

Tab. S4 - ANOVA results for leaf water evaporative enrichment $\left(\Delta^{18} \mathrm{O}_{\mathrm{L}}\right)$ by selected decades.

Tab. S5 - ANOVA results for the ratio between intercellular $\mathrm{CO}_{2}$ concentration $\left(\mathrm{C}_{\mathrm{i}}\right)$ and atmospheric $\mathrm{CO}_{2}$ concentration $\left(C_{a}\right)$ by selected decades.

Tab. S6 - Regression results of Fig. 4.

Link: Palandrani_3414@supploo1.pdf 